\title{
Comparison of the reinforcing properties of conditioned and discriminative stimuli in new and previously experienced environments*
}

\author{
J. DUTCH \\ Victoria University of Wellington, Wellington, New Zealand
}

\begin{abstract}
Drinking in rats was either preceded or accompanied by a tone. When barpressing was subsequently conditioned to the tone, it was found that more barpresses were made in a totally new environment than in the environment in which conditioning of the tone had taken place. Within each environment, there was no difference in the effectiveness of the tone stimuli.
\end{abstract}

It has been suggested (Skinner, 1938; Keller \& Schoenfeld, 1950) that it is necessary for a stimulus to be a discriminative stimulus $\left(S_{\mathbf{D}}\right)$ in order that it may also be a secondary reinforcer. The purpose of the following experiment is to test this hypothesis using the new response procedure.

\section{METHOD}

\section{Subjects}

The Ss were 64 male Sprague-Dawley rats from the Victoria University colony, approximately 100 days old at the commencement of the experiment.

\section{Apparatus}

The Ss were conditioned in a modified Lehigh Valley Electronics, Inc., small-animal test chamber enclosed in a sound-insulation cubicle equipped with a blower. White noise of $70 \mathrm{~dB}$ was present except at the times when the stimuli to be conditioned occurred. Both bars were removed, and the box was illuminated by a white houselight. The box was modified by replacing the mechanized liquid dipper with a silent motor-driven dipper, and by surrounding the dipper entry with a rectangular aluminum band $4 \times 4 \times 7 \mathrm{~cm}$ high. The CS was a 2 -sec presentation of a $2-\mathrm{KHz}$ tone.

The Ss were tested either in the same box in which they had been conditioned or in a second Lehigh Valley chamber which was modified in the following ways. First, the grid floor and four walls were covered with black painted sheet aluminum, after all the standard interior fittings, including the dipper housing, had been removed. A slot was left in one wall for inserting the lever. Second, the chamber was housed in a varnished wooden cubicle which held a light bulb and the speaker. In short, every effort was made to ensure that the two chambers were dissimilar.

\section{Procedure}

Two weeks before the commencement of the experiment, Ss were placed on a 23.5 -h water-deprivation schedule with ad lib food. Conditioning was conducted over 10 days, each $S$ being given 60 pairings of stimulus and reinforcement each day. Conditioning trials were scheduled as follows: for the contiguous groups, contact with the loaded dipper produced the tone for $2 \mathrm{sec}$ and started a program which operated the water dispenser $15 \mathrm{sec}$ later on the average. The time between trials was, therefore, a joint function of the behavior of $S$ and the

*This paper is sponsored by H. N. Schoenfeld, who takes full editorial responsibility for its contents. experimental program, but there was at least an average of $15 \mathrm{sec}$ between reinforcements. Similar scheduling was used for the groups which received the tone $2 \mathrm{sec}$ before water was delivered ( $S_{D}$ groups). Contact with the loaded dipper started a program which operated the tone $13 \mathrm{sec}$ later, on the average. Immediately after the tone ceased, the water dispenser was operated. Thus, for both conditions, the minimum intertrial time was $15 \mathrm{sec}$, but in both conditions Ss could increase the intertrial time by failing to make contact with the loaded dipper.

Testing commenced on the day following the completion of conditioning. During testing, a lever was inserted into both chambers, and every leverpress was followed by a 2-sec presentation of the tone.

\section{Experimental Design}

At the commencement of conditioning, the Ss were randomly assigned to either the contiguous or the $S_{D}$ condition. At the commencement of testing, the 32 Ss in each condition were randomly assigned to one of four groups. There were thus eight groups in all. Ss were tested in the new or the old environment, with the stimulus either following or not following each leverpress.

\section{RESULTS AND DISCUSSION}

Table 1 shows the mean number of leverpresses made during testing. An analysis of variance was performed on the scores, $F(7,56)=8.81, p<.01$. The group means were compared, using Duncan's new multiple range test at the .05 level. It was found that there was no significant difference between groups receiving the tone in the new box, but both these groups made significantly more responses than any other group. There was no significant difference between groups receiving the tone in the old box, but they both made significantly more responses than any group which did not receive the tone. There was no significant difference between the groups receiving no tone.

From these results, it is clear that a stimulus need not be an $S_{D}$ in order for it to become a secondary reinforcer and that a stimulus associated with reward on the basis of contiguity alone is as effective a secondary reinforcer as a stimulus which had an $S_{D}$ function in conditioning. The other result of interest is the lower 
Table 1

Mean Number of Responses During Testing

\begin{tabular}{ccccccccc}
\hline $\begin{array}{c}\text { Training } \\
\text { Conditions }\end{array}$ & Contiguous & $\mathrm{S}_{\mathbf{D}}$ & $\mathrm{S}_{\mathbf{D}}$ & Contiguous Contiguous & $\mathrm{S}_{\mathbf{D}}$ & $\mathrm{S}_{\mathbf{D}}$ & Contiguous \\
$\begin{array}{c}\text { Testing } \\
\text { Conditions }\end{array}$ & $\begin{array}{c}\text { New Box } \\
\text { Tone }\end{array}$ & $\begin{array}{c}\text { New Box } \\
\text { Tone }\end{array}$ & $\begin{array}{c}\text { New Box } \\
\text { No Tone }\end{array}$ & $\begin{array}{c}\text { New Box } \\
\text { No Tone }\end{array}$ & $\begin{array}{c}\text { Old Box } \\
\text { Tone }\end{array}$ & $\begin{array}{c}\text { Old Box } \\
\text { Tone }\end{array}$ & $\begin{array}{c}\text { Old Box } \\
\text { No Tone }\end{array}$ & $\begin{array}{c}\text { Old Box } \\
\text { No Tone }\end{array}$ \\
\hline Mean & 80.7 & 100.6 & 3.1 & 2.7 & 21.6 & 34.0 & 5.2 & 2.0 \\
\hline
\end{tabular}

secondary reinforcing strength of stimuli tested in the apparatus in which conditioning took place. The most likely explanation for this finding is that the continuous presence of stimuli associated with reward acted as an information source confirming the absence of reward, or that Ss spent time and energy at the reward source, thus rendering the tone stimulus less effective.

\section{REFERENCES}

Keller, F. S., \& Schoenfeld, W. N. Principles of psychology. New York: Appleton-Century-Crofts, 1950.

Skinner, B. F. The behavior of organisms: An experimental analysis. New York: Appleton-Century-Crofts, 1938

(Received for publication April 22, 1974.) 